\title{
Social Capital and Constraints on Legal Careers
}

\section{Ronit Dinovitzer}

\begin{abstract}
This article focuses on the role of social capital in lawyers' careers by examining the career outcomes of Jewish lawyers. Although research on the legal profession has emphasized social capital as an inherently positive resource, this article conceptualizes social capital as multivalent, with the potential for both positive and negative effects. Drawing on five forms of social capital and examining four separate outcomes (type of practice setting, prestige of field of practice, satisfaction, and income), the analyses demonstrate that particular forms of social capital are indeed related to diverging outcomes. This study finds positive effects for the social capital that derives from reciprocity exchanges, but it also finds that the social capital built through dense social ties can lead to less successful professional settings. The conclusion explores the possibilities this raises for understanding the interplay between religion, capital, and legal careers.
\end{abstract}

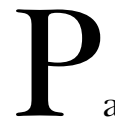
of power and prestige in the legal profession (Heinz, Nelson et al. 2001). Research has focused on identifying who gains access to these positions, finding that social background, law school credentials, grades, and gender are salient determinants in this sorting process. In more recent years, research on the profession has identified that another important resource-social capital-further distinguishes those who attain these prestigious positions from those who do not. Social capital, a concept drawn primarily from Bourdieu (1986) and Coleman (1988), has been broadly defined in prior research as a resource that promotes successful legal careers - so that achievement within the bar is predicated on membership in organizations, networks of friends, family, community members and colleagues, or professional activities outside of one's workplace.

The research and writing for this article were supported by the Law School Admission Council and the Social Sciences and Humanities Research Council of Canada. I am grateful to Bryant Garth, Ron Gillis, John Hagan, Ron Levi, and participants in the colloquium series at Northwestern University's Department of Sociology for their helpful comments and insights. Please address correspondence to Ronit Dinovitzer, Department of Sociology, University of Toronto, Toronto, Canada M5S 2J4; e-mail: ronit.dinovitzer@utoronto.ca.

Law E Society Review, Volume 40, Number 2 (2006)

(C) 2006 by The Law and Society Association. All rights reserved. 
In documenting the social structure of the bar, social capital has been conceived of as univalent: social capital allows individuals to build successful careers, and a lack of this resource keeps others from succeeding. This generally follows Coleman's model, in which social capital is regarded as inherently productive, "making the achievement of goals possible" (1988:S98). Kay and Hagan, for example, determine that networking social capital-defined as the extent of personal contacts and institutional clients - is "crucial to advancement within the firm" (1999:542). Similarly, social capital is found to increase the likelihood of partnership, whether through the benefits enjoyed through "time-dependent social capital" (Kay \& Hagan 1999:542) or as a result of membership in associations, involvement in professional activities, or embeddedness in client networks (Kay \& Hagan 1998:737). Research also finds that prestigious social networks are related to the likelihood of working in more-prestigious fields of law (Heinz et al. 2005), so that the availability of social capital translates into higher earnings (Hagan 1990; Heinz et al. 2005; Dixon \& Seron 1995; but see Robson \& Wallace 2001). At the same time, studies find that the beneficial effects of social capital can be gendered (Reichman \& Sterling 2002; Kay \& Hagan 1998), ${ }^{1}$ and limited social capital is identified as a cause of inequality: for instance, Wilkins (2004) argues that for black lawyers, a lack of social capital in the form of elite networks maintains or reinforces their disadvantage in the profession, and that "contacts are ultimately what will allow [black lawyers] to be a successful partner" (2004:27) because large firms place a premium on the ability to develop, manage, and exploit client relationships (but see Garth 2004).

Yet sociological research on social capital in other domainsparticularly within the field of ethnicity and immigration studiesalerts us to social capital's multivalent nature. Certainly, the mobilizing of social capital underlies the success of many immigrant communities - whether by ensuring access to start-up capital for ethnic entrepreneurs (Light \& Bonacich 1988; Nee et al. 1994), providing jobs for recent immigrants (Doeringer \& Moss 1986; Bailey \& Waldinger 1991; Waldinger 1996; Stepick 1989), or encouraging familial support for higher educational attainments by immigrant children (Dinovitzer et al. 2003; Stanton-Salazar \& Dornbush 1995). But as counterintuitive as it may seem, this research

1 For example, Kay and Hagan (1998) find that certain forms of social capital (such as bringing in clients and engaging in professional activities) lead to payoffs for women, while others (such as association memberships) pay off only for men. Though these forms of social capital work differently for men and women, these findings continue to emphasize social capital as a positive resource that leads to successful legal careers. 
also suggests that social capital may be the reason that some fail to succeed. This research has highlighted the potential for social capital to work as a negative resource, one that constrains rather than enables, or that levels norms downward rather than up (Portes 1998:15). For example, Geertz's (1963) classic study of entrepreneurs in Bali finds that ethnic businesses were constrained by norms that encouraged assistance to community members, thereby turning what would have been "promising enterprises" into "welfare hotels."

Portes and Sensenbrenner (1993) (see also Portes 1998) isolate at least three ways in which social capital can have negative, rather than positive, effects. First, they identify the "free rider" problem in cohesive communities, with less-successful community members placing demands on those more successful than them, as in the example of Geertz's research above. A second negative effect is the possibility of constraint on individual freedom. In the tightly knit community of San Francisco's Chinatown, for example, families regulate business and social life: so while community members benefit from a privileged access to resources, the cost is one of conforming to the dominant families' conservative tendencies (Nee \& Nee 1974). The third negative effect is downward leveling norms, which prevent individual community members from aspiring to mainstream goals. This pattern emerges in communities where solidarity is based on a common adversity. Classic examples are found in the experiences of inner-city ethnic youth, whether it be the stigma attached to Puerto Rican "turnovers" who seek to join the middle-class mainstream in New York (Bourgois 1995), or "acting White" in black communities (Fordham \& Ogbu 1986). "In these instances," Portes explains, "success stories undermine group cohesion because the latter is precisely grounded on the alleged impossibility of such occurrences" (1998:17).

The negative effects of social capital are not only manifested through community norms. Research on labor markets highlights that certain forms of social capital may be more beneficial than others. This is most convincingly argued by Granovetter (1974), who finds that job seekers with dense social ties - a source of social capital according to most researchers - may in fact be disadvantaged on the job market. Immersion in dense social networks, Granovetter finds, restricts the information that job seekers receive about newly available jobs. On the other hand, advantages accrue to job seekers with weak ties - a different form of social capital. Granovetter finds that acquaintances, rather than close friends, can provide job seekers with otherwise unknown information regarding job opportunities because they move in different social circles (1974:52). 
The point is not merely that social capital can be "negative." Instead, social capital in and of itself is not a positive or a negative resource. As Bourdieu (1986) explains, individuals accumulate various forms of capital - whether it be social, cultural, or human capital-but this capital must often be converted into a different form before it can be successfully mobilized as a resource (see also Bourdieu 1977:184). For example, social capital such as friendship networks can be converted into a financially lucrative position; a successful athlete who has capital related to his or her sport may convert this into money through product endorsements (Calhoun 2003:294-5); and an Ivy league education allows wellheeled parents to convert their financial capital into a legitimate credential for their children, though to be successful this conversion relies on their children's own investment in the educational field (Dezalay 1995a; Wacquant 1998; Calhoun 2003). This ability to convert capital, however, is dependent not only on skill but also on one's position in social space, so that not only is the availability of social capital unequal, but so too are the payoffs received in exchange for one's capital (see also Lin 2000). Simply put, to be productive social capital must be successfully marshaled by those situated individuals who can convert it into a meaningful resource.

This article seeks to develop research on social capital and the legal profession by focusing on social capital as a multivalent resource. Since much of the research that finds diverging effects of social capital derives from studies of ethnicity and immigration, this article takes the occasion to build our understanding of lawyers' careers by drawing together these two otherwise disparate strands of research. I do so through access to unique data that lie at the intersection of research on the legal profession and studies of ethnicity and immigration: set against the backdrop of the social, political, and historical setting of the Canadian provinces of Quebec and Ontario - and of Montreal and Toronto - these data are based on a study of lawyers facing a professional and personal transition, in which the successful mobilization of social capital plays a crucial role in their career paths.

This study traces the legal careers of Jewish and non-Jewish lawyers who face a political and economic landscape that prompts them to leave Montreal and build their careers in a new setting. Paying attention to this context allows us to explore the experiences of a particular ethnic group-Jewish lawyers - through a migration in which the many forms and effects of social capital in the legal profession can be examined. I begin by outlining the history of Jewish lawyers. The article then turns to the specific socio-historical context of the study and describes the research design and analysis, before turning to the broader discussion of the 
relationship between social capital, ethnic ties, and the structure of legal careers.

\section{Jewish Lawyers}

The history of Jewish lawyers in both the United States and Canada is one of exclusion, with Jewish lawyers - even those with elite credentials - underrepresented in the profession's most elite positions. In Unequal Justice, Auerbach (1977) characterized the early history of the legal profession as one in which Jews were outsiders whose entry into the profession and its more elite settings was controlled by quotas, tacit recruitment policies, educational standards, and credentials (Auerbach 1977:108; see also Nigro \& Mauro 1999). This helps explain the predominance of Jews in solo private practice: Ladinsky's 1960 study of lawyers in Detroit found that Jews comprised $35 \%$ of all solo practitioners, but only $6 \%$ of lawyers within firms (1963:131, Table 1); Arthurs et al.'s 1971 study of Toronto lawyers found that the percentage of Jewish lawyers in solo practice was double the number of non-Jewish lawyers $(27 \%$ versus 12\% overall), while a study of the Montreal Bar in 1968 also confirmed that Jewish lawyers were working in smaller firms (Belanger et al. 1968, cited in Nigro \& Mauro 1999:1038); in New York, Carlin (1966) found a similar pattern with Jews comprising $77 \%$ of solo practitioners but only $25 \%$ of firms of 15 or more lawyers; and a study of Yale law school graduates concluded that Jewish graduates in New York worked in firms that were smaller than the average (Yale Law Journal 1964). A decade later, the landmark Chicago Lawyers study continued to find a bar that was segmented along ethno-religious lines, with Jewish lawyers overrepresented in low-prestige legal work (Heinz \& Laumann 1994:133-6), and only $38 \%$ as likely as Protestants to be in senior positions (Heinz et al. 2005:156) - a history of segmentation of practice settings and specializations that parallels the experience of other ethnic and religious minorities in the bar, most notably Catholics (Heinz \& Laumann 1994; Carlin 1994). ${ }^{2}$

In larger and "white shoe" law firms, Jewish lawyers were excluded from positions of power and authority, maintained mostly

${ }^{2}$ The ethno-religious differentiation found in Chicago also correlated with a segmentation into particular areas of specialization; Jewish lawyers, for example, tended to work in the less-prestigious personal client hemisphere, working in fields such as divorce, labor law, or criminal defense (Heinz \& Laumann 1994:136; Heinz et al. 2005:62). In a similar fashion, Catholic lawyers were overrepresented in personal injury work, business litigation, and general litigation, and as prosecutors (Heinz \& Laumann 1994; Parikh \& Garth 2005). 
by the profession's Protestant elite. ${ }^{3}$ Interviews with partners in New York in the 1960s indicated that firms were hesitant to become identified as "Jewish firms" because it would harm their ability to recruit associates. "[T] he firm that gets the talent gets the business .... becoming known as a Jewish firm would severely limit the number of qualified Gentiles who would apply to them in the future" (Yale Law Journal 1963:651). As Dezalay suggests, respectable law firms remained the preserve of the gentlemen of an "old guard," with young, ambitious - but ethnic, often Jewish - professionals being kept at bay (1995b:80-2, 95-6). ${ }^{4}$ And there is evidence that Jewish lawyers themselves would walk a tightrope to balance their status and their ethnicity, in an effort to avoid jeopardizing their precarious positions (see, e.g., Woeste 2004).

The legal landscape, however, would soon change. As many have documented (Heinz, Nelson et al. 2001; Halliday 1986), the 1980s financial boom was mirrored in the work available across the legal profession, and particularly in elite, large corporate law firms: the number of lawyers nearly doubled between 1971 and 1995, to more than 800,000 lawyers (Heinz, Nelson et al. 2001), the number of firms with more than 100 lawyers increased by $196 \%$ between 1980 and 1988 (Nelson 1994:345), and total U.S. expenditures on legal services grew from $\$ 32$ billion in 1972 to $\$ 101$ billion in 1992 in constant (1992) dollars (Bureau of the Census 1976, 1996, cited in Heinz et al. 2001:338). The Canadian legal profession experienced a parallel growth, though on a somewhat smaller scale (Kay \& Hagan 1999; Daniels 1993; Arthurs 1996). At the same time that this growth was demanding an increased number of lawyers, the profession was experiencing the breakdown, or at least a weakening, of many of the earlier social and professional barriers - for women and racial and religious minorities in both the United States and Canada.

As a result, many have extolled the contemporary legal profession as one in which the former barriers were "swept away" (Galanter \& Palay 1991:57; see generally Silberman 1985). For in-

${ }^{3}$ A number of studies at the time struggled with this issue and debated whether there was discrimination against Jews or whether it was an issue of "choice" - that Jewish lawyers expected to find discrimination, and therefore did not apply to work in larger firms (Arthurs et al. 1971; Yale Law Journal 1964).

${ }^{4}$ In both Toronto and Montreal, for example, some prominent large firms did not have any Jewish lawyers through the 1950s and even the 1960s (Wilton 1996; Cole 1996; Nigro \& Mauro 1999). Regehr's historical account of Blake, Cassels, \& Graydon, currently one of Canada's most prominent business law firms with more than 500 lawyers, neatly captures the status of Jews in the Toronto legal profession: "As late as the 1950s, when the firm wanted to hire additional staff, a junior partner inquired about the firm's attitude with respect to the hiring of a Jewish lawyer. The matter had never come up before, but after RCH Cassels made discreet inquiries at the Toronto Club, he returned with the report that "it would be the end of the Blake firm." (1996:214) 
stance, Hagan et al. (1988:39) find that while Toronto Jews continue to be overrepresented in small firms, Jews who entered the profession in the 1980 s are now working in equal proportion to White Anglo-Saxon Protestants in large and elite firms. And Erlanger's (1980:893) national U.S. data find that Jewish lawyers are distributed evenly among firms of different sizes (though this was not true for New York [1980:896]), suggesting instead that status attainment in the bar is better predicted by educational attainment than religious affiliation.

Yet even with the demographic shifts coming on the heels of law firm expansion, there are continued signs of ethnic stratification. Hagan et al. (1988) find that $60 \%$ of Toronto Jews seeking positions in large firms have received them, compared with $77 \%$ of White Anglo-Saxon Protestants (Hagan et al. 1988:38, Table 11). They also find that Jewish lawyers continue to be less likely to be partners in large elite firms, even controlling for credentials and numbers of years in practice (1988:45), and they are also less likely to begin their careers in large firms. Lena et al.'s 1993 analysis of a national sample of lawyers in mid-career who all began practice in 1961, found that religion continues to be an important marker, with an underrepresentation of Jewish (and Catholic) lawyers in higher-status firms and an increased likelihood of Jewish lawyers in solo practice.

More recent data are found in Urban Lawyers (Heinz et al. 2005), which interviewed nearly 800 lawyers in 1995. These data reveal a persistent opportunity structure in which race, religion, and gender are associated with differential rates of partnership in large law firms. Jewish males, both in 1975 and in 1995, were less likely than white male Type I Protestants (Episcopalians, Presbyterians, and Congregationalists) to be partners in large firms (Heinz et al. 2005:67). In 1975, the likelihood of a Jewish male to attain such a position was $3 \%$, compared with $14 \%$ for the men in the majority group, while in 1995 the likelihood for Jews was $11 \%$, compared with $26 \%$ for the majority group. ${ }^{5}$ At least in Chicago, the bar continues to be somewhat demarcated by ethno-religious affiliations, ${ }^{6}$ and Jewish lawyers, although overrepresented in more elite law schools and enjoying more privileged backgrounds,

5 At the same time that they find this continued segmentation of the profession, Heinz et al. (2005) find that Jewish lawyers are just as likely to be earning incomes in the top quartile compared with White Anglo-Saxon Protestants. Similarly, Hagan and Kay find no significant effect of having a White Anglo-Saxon Protestant background on earnings in their study of Toronto lawyers (1995:141, Table 6.2).

${ }^{6}$ However, it is also true that in 1995 , there were no significant correlations between overall characteristics of the particular fields of practice, including client type, and the percentages of Jewish lawyers in the fields (Heinz et al. 2001). 
continue to be less likely to attain partnership status and success in large law firms. ${ }^{7}$

\section{Research Design}

The data for this article derive from a study of Canadian lawyers who left Montreal for the neighboring province of Ontario between 1975 and 1990. This time frame captures major periods of political change within Quebec, including the 1976 election of a government that sought political and economic separation from the remainder of Canada, a significant outmigration of Englishspeakers from Montreal to Toronto, and a referendum on political sovereignty in 1980. It is important to note that these lawyers who moved are also important political actors (see generally Halliday \& Karpik 1998; Shamir 1995): as Professor Yves-Marie Morrissette, a former Dean of McGill University's Law School, has commented, "[t]hese lawyers leaving are going to have a very negative impact on the bar, and not to see that is either willful blindness or crass ignorance" (Westhead 1996:18).

The sampling frame was constructed through archival research at the Law Society of Upper Canada (the regulatory body for lawyers in Ontario), which revealed that a total of 515 lawyers moved from Quebec to Ontario during this time period. ${ }^{8}$ Some Quebec lawyers, to be sure, moved elsewhere, but with the rise of Toronto as the dominant locale in the Canadian legal profession, and with Ontario being the primary destination for Quebec outmigrants more generally (Ram et al. 1994: 43-4, Table 5.4), it is this specific migration flow that is critical. Relying on the eligibility criteria described below, this article thereby focuses on the experience of lawyers who left the city of Montreal to build their careers in Ontario.

Data were collected using a 25-page mail-back survey that included questions about respondents' education and professional training, job satisfaction, opportunities and conditions of work, professional work history, and demographic information. The questionnaire also offered respondents an opportunity to contribute any

7 It should be noted that in 1995, Jews were overrepresented in elite law schools in Chicago but were also overrepresented at Chicago-Kent, one of the less-prestigious local schools (Heinz et al. 2005:62). This further suggests that there is a pattern of ethnoreligious demarcations that extend before entry into the legal profession.

${ }^{8}$ Since all practicing lawyers must be licensed through the Law Society of Upper Canada, the records of this governing body are the most reliable source for constructing the sampling frame. The Law Society's records indicate the name of the law school attended for each admittee. By restricting the sample to those lawyers educated in Quebec, the analyses in this article can assess the impact of migration by holding the location of education constant. 
comments about their experiences in moving from Quebec to Ontario. After adjusting for attrition due to death and for members since disbarred from the Ontario profession, the final response rate was $56.4 \%(\mathrm{n}=279)$. To ensure that the final sample excluded law graduates who were living in Quebec solely for their legal education, the eligibility criteria required that only those lawyers who were born in Quebec, grew up in Quebec, or had parents living in Quebec at the time of their move were included. This final sample of 216 respondents comprised lawyers who all completed their legal education at McGill University's Faculty of Law, an elite Canadian institution located in Montreal and the only Quebec university to offer the common law degree required for legal practice in Ontario.

\section{The Montreal Jewish Community}

Although European Jews began moving to Montreal as early as 1768, the Jewish community experienced a rapid expansion with the influx of eastern European shtetl immigrants fleeing poverty and persecution in the late 1800s (Szacka 1984b). These new immigrants remained poor, working as laborers or as traveling peddlers. Central to their lives was a commitment to yiddishkayteastern European Jewish culture - with material survival taking second place "to the task of perpetuating tradition" (Langlais \& Rome 1991:30; see generally Robinson \& Butovsky 1995:15). By the early 1900s, Montreal became the center for "summits" of Yiddish culture, with the new Montreal Jews being generally Zionist, religious, and responsive to the arts, with this common goal being shared by a full cross-section of its members, from its bakers and teachers to its poets and bankers (Robinson \& Butovsky 1995:18-9). Jewish migration to Montreal expanded in the 1940s and $1950 \mathrm{~s}$, with an influx of Holocaust survivors moving to the city (Szacka 1984a:109; Weinfeld 1993:187).

Establishing their residential and cultural community in an area of downtown Montreal known as the "Main," the Jewish community created a distinct enclave by living and working in a neighborhood at the boundary of the English and French-speaking sections of the city (Robinson \& Butovsky 1995:16). In 1971, Irving Layton, a Montreal poet, vividly expressed the troubled relation of the Jews to these two sectors of Montreal:

In Montreal the dominant ethnic groups stared at one another balefully across their self-erected ghetto walls. Three solitudes. I remember the feelings of anxiety I had as a boy whenever I crossed St. Denis Street. This street marked the border between the Jewish and French-Canadian territories. East of St. Denis was 
hostile Indian country densely populated with church-going Mohawks somewhat older than myself waiting to ambush me ... walking westward, took me into that other ghetto, the one where the Anglo-Saxons lived in tree-lined and privileged aloofness ... Here I always felt myself to be a trespasser, not a warrior as I did when I crossed St. Denis Street. At any moment huge mastiffs would be loosed on me or someone with a healthy tanned face would say to me with cold but perfect English diction: "Get away from here." (Irving Layton, cited in Robinson \& Butovsky 1995:168).

The social distance of the Montreal Jewish community was exacerbated by official anti-Semitism, including publicly endorsed economic boycotts and opposition to Jewish immigration (Delisle 1993; Langlais \& Rome 1991:86; Weinfeld 1993:186). Because Quebec's educational, charitable, and relief agencies were organized along the confessional lines of the Catholic and Protestant communities, the Jews remained without legal status in public institutions (Rosenberg \& Jedwab 1992:274). This reinforced Jews' status as the "third solitude" (Brown 1986:235) in Quebec, being neither English nor French (see generally MacLennan 1957), and discriminated against by both - an anti-Semitism that continues to be more widespread than in other Canadian provinces (Sniderman et al. 1993).

As early as the $1940 \mathrm{~s}$, the Jewish community established a broad range of social institutions (Jedwab 1995:44; Breton 1964), including labor organizations, schools, youth movements, and benefit societies (Torczyner \& Brotman 1994:12). As others document (Robinson \& Butovsky 1995:18) and Richler (1961) vividly recounts, Montreal Jews lived in an ethnic enclave (see generally Portes 1998:13) - an "almost self contained world" (Richler 1961:140) where political, social, and even sporting events could simply be interpreted as whether they were "good for the Jews" (Richler 1961:139), with a sense that "as long as the English and French were going at each other they left us [the Jews] alone" (Richler 1961:139).

This ethnic enclave persisted for the children of these immigrants, even as the community prospered. In a 1978 study of Montreal Jews, Weinfeld (1980:10) found that nearly $70 \%$ of respondents had a Jewish employer, with $73 \%$ reporting that some, most, or all of their business associates were Jewish ${ }^{9}$ - reflecting a typical ethnic enclave as defined by Portes (1998:13). The Montreal Jewish community remained, in many ways, economically, resi-

9 This pattern held true for the Jewish community's professionals (including its lawyers) and its more affluent members, with more than half of these Montreal Jews reporting that all or most of their clients were Jewish (Weinfeld 1980). 
dentially, and socially segregated. Despite its members moving away from original settlement neighborhoods, Weinfeld (1980) found that $87 \%$ of respondents reported that all or most of their friends were Jewish, and more than $50 \%$ reported that all or most of their neighbors were Jewish. Studies also indicate that compared with Jews elsewhere in Canada, large majorities of Montreal Jews continued to observe religio-cultural rituals, provide Jewish education for their children, have lower rates of intermarriage, travel to Israel, and report high levels of participation in Jewish cultural life (Brodbar-Nemzer et al. 1993:71; Torczyner \& Brotman 1994; Weinfeld 1980:7).

Changes, however, were underway in the Quebec political landscape. Since the 1960 s, political debate in the province has focused on preserving French language and culture, and on the possibility of Quebec's independence from the rest of Canada. This has included legislation restricting the use of English on commercial signs and access to English-language schooling, and referendums on political sovereignty in 1980 and $1995 .^{10}$

Meanwhile, English-speaking Quebeckers began leaving the province in large numbers. Between 1971 and 1976, almost 100,000 English-speakers left for another province in Canada, with an additional 230,000 leaving between 1976 and 1990 (Maheu 1983:272; Ram et al. 1994: 43-4, Table 5.4). ${ }^{11}$ The majority of migrants moved to Toronto, in the neighboring province of Ontario (Jedwab 1996:44). ${ }^{12}$ Ontario comprises one-third of the Canadian population, includes the nation's capital (Ottawa) as well as its financial center (Toronto), and contributes $41 \%$ of Canada's gross domestic product. Montreal Jews soon figured prominently in this outmigration from Quebec. Between 1971 and 1981, the number of English-speaking Montreal Jews declined by 20\%, with a net loss of more than 15,000 people; this decade marked the first decrease in Montreal's English-speaking Jewish population, which had enjoyed a strong and steady growth since the 1930s (Rudin 1986:176; Shahar 2003). ${ }^{13}$ Over the 1980s and 1990s, it is esti-

${ }^{10}$ In $1980,59.5 \%$ of voters voted against the proposed "sovereignty-association" with English Canada, and in 1995, 50.6\% of voters voted against sovereignty. These issues remain disputed, with the 2003 government committed to holding a third referendum when "winning conditions" arise (Wyatt 1998).

11 The definition of Anglophone on the Canadian census has changed over the years. Currently, the Canadian census contains a number of definitions of Anglophone-Anglophone by mother tongue, Anglophone by "home language," and Anglophone by ethnic origin. These numbers reflect the Anglophone population based on mother tongue.

12 Given the migration from Ontario to Quebec, this resulted in a net loss of nearly 150,000 English-speakers in this migration exchange alone (Jedwab 1996:44).

13 The number of Jews who left the province is likely higher than these numbers suggest, since this time period also saw a large influx of North African Jews, largely Frenchspeaking, who replenished the Montreal Jewish population. Based on census figures, 
Table 1. Measures of Social Distance by Religious Identification

\begin{tabular}{|c|c|c|}
\hline & Jewish & $\begin{array}{c}\text { All } \\
\text { Other }\end{array}$ \\
\hline \multicolumn{3}{|l|}{ Language \& Background } \\
\hline Respondents' father was an employee & $22.8 \%$ **** & $61.8 \%$ \\
\hline Respondents' father was a business owner & $63.4 \%^{* * * * *}$ & $18.2 \%$ \\
\hline Respondents' mother tongue is English & $95.0 \%$ **** & $77.7 \%$ \\
\hline $\begin{array}{l}\text { High French proficiency (greater than } 16 / 20 \text { ) (ratings of knowledge of } \\
\text { French on a scale from one to five in each of the following areas: aural } \\
\text { comprehension, speech, writing, and reading) }\end{array}$ & $18.2 \%$ *** & $35.8 \%$ \\
\hline \multicolumn{3}{|l|}{ Respondent occasionally or usually: } \\
\hline Worked in a primarily Francophone organization & $39.1 \%$ & $48.5 \%$ \\
\hline Worked closely with Francophones & $52.1 \% *$ & $69.5 \%$ \\
\hline Spoke French regularly & $67.7 \%$ *** & $84.1 \%$ \\
\hline Lived in a Francophone community & $12.9 \%$ **** & $53.4 \%$ \\
\hline Socialized with Francophones & $51.0 \%$ **** & $81.0 \%$ \\
\hline Studied closely with Francophones & $55.1 \%$ **** & $76.5 \%$ \\
\hline \multicolumn{3}{|l|}{ Respondent had at least infrequent personal encounters with: } \\
\hline Ethnic/racial discrimination & $59.2 \%$ *** & $30.8 \%$ \\
\hline Language discrimination & $81.5 \%$ & $70.6 \%$ \\
\hline Religious discrimination & $63.6 \%$ **** & $6.5 \%$ \\
\hline
\end{tabular}

Tests of significance for Jewish respondents compared to non-Jewish respondents: ${ }^{*} p<0.05,{ }^{* *} p<0.01,{ }^{* * *} p<0.001$ (two-tailed)

mated that an additional 20,000 Montreal Jews left the city (Norris 1999), with a continued decline being projected for the community to this day (Arnold 2005). ${ }^{14}$

\section{Data and Findings}

This article situates the career trajectories of lawyers within this outmigration of Montreal Jews, focusing on a group of lawyers who left Quebec between 1975 and 1990. I first explore the range of networks and social connections among these lawyers to identify their potential sources of social capital, and I then examine the relationship between social capital and career outcomes - examining whether, and with what effects, social capital is deployed as these migrants build their legal careers in a new city.

Nearly half of the respondents report their religious identification as Jewish $(n=101)$. These Jewish respondents share some central demographic characteristics: nearly half are the children of immigrants, $78 \%$ are men, $92 \%$ are married, and $97 \%$ were born in Canada. In addition, Table 1 highlights that the socioeconomic status of Jewish respondents differs from that their non-Jewish

between 1971 and 1981 the Montreal Jewish community lost about 6\% of its total population, dropping from 109,485 to 103,425 , with an additional $2 \%$ loss between 1981 and 1991 (Torczyner \& Brotman 1994).

${ }^{14}$ Many were likely young. Weinfeld and Eaton (1979) found that $34 \%$ of the children of the Jewish households in their sample had already left Montreal, and an additional 25\% would leave Quebec within five years (Weinfeld \% Eaton 1979:78-80). In 1977, 45\% of Jewish university students expected to leave the province (Brown 1986:266). 
Table 2. Motivations for Leaving Quebec and Moving to Ontario (Very or Somewhat Important) by Religion

\begin{tabular}{|c|c|c|c|c|}
\hline & \multicolumn{2}{|c|}{ Leaving Quebec } & \multicolumn{2}{|c|}{ Move to Ontario } \\
\hline & Jewish & Non-Jewish & Jewish & Non-Jewish \\
\hline Political conditions & $91.8 \%$ **** & $72.1 \%$ & $60.7 \%$ & $55.4 \%$ \\
\hline Language laws in Quebec & $81.1 \%$ **** & $57.1 \%$ & - & - \\
\hline Professional opportunities & $72.8 \%$ & $67.3 \%$ & $74.2 \%$ & $78.7 \%$ \\
\hline Economic conditions & $69.5 \%$ & $68.0 \%$ & $71.3 \%$ & $70.3 \%$ \\
\hline Race relations/ethnic relations & $51.6 \%$ & $44.1 \%$ & $40.7 \%$ & $27.0 \%$ \\
\hline Location chosen to raise children & $51.1 \% * *$ & $32.3 \%$ & $46.9 \%$ & $33.0 \%$ \\
\hline Job offer for yourself & $49.5 \%$ & $75.8 \% * * * *$ & $60.7 \%$ & $76.5 \%$ \\
\hline Dis/satisfaction with governmental services & $42.2 \%$ & $29.3 \%$ & $19.0 \%$ & $18.6 \%$ \\
\hline Desire to be amongst more English-speakers & $40.7 \% * *$ & $20.7 \%$ & $43.2 \% * * *$ & $20.7 \%$ \\
\hline To increase household income & $36.8 \%$ & $44.2 \%$ & $38.8 \%$ & $49.4 \%$ \\
\hline Dis/satisfaction with legal community & $29.8 \%$ & $23.1 \%$ & $39.5 \%$ & $43.7 \%$ \\
\hline Job offer for spouse & $15.7 \%$ & $15.9 \%$ & $19.5 \%$ & $16.5 \%$ \\
\hline To be closer to spouse/family & $10.5 \%$ & $22.6 \% *$ & $27.8 \%$ & $34.4 \%$ \\
\hline For a change & $8.4 \%$ & $20.2 \% *$ & - & - \\
\hline Dis/satisfaction with neighborhood & $8.3 \%$ & $5.7 \%$ & $22.8 \%$ & $12.8 \%$ \\
\hline To be closer to friends & $6.9 \%$ & $6.5 \%$ & $26.3 \%$ & $18.9 \%$ \\
\hline My clients were leaving Quebec/were in Ontario & $5.0 \%$ & $8.3 \%$ & $5.3 \%$ & $3.7 \%$ \\
\hline Cost of living & $5.0 \%$ & $3.4 \%$ & $3.8 \%$ & $9.3 \%$ \\
\hline Climate & $3.7 \%$ & $5.7 \%$ & $2.5 \%$ & $4.7 \%$ \\
\hline To be closer to community members & $2.3 \%$ & & $15.2 \% * *$ & $2.3 \%$ \\
\hline Dis/satisfaction with entertainment & & $1.2 \%$ & $22.8 \%$ & $12.8 \%$ \\
\hline
\end{tabular}

Tests of significance for Jewish respondents compared to non-Jewish respondents: $* p<0.05,{ }^{* *} p<0.01,{ }^{* * * *} p<0.001$ (two-tailed)

counterparts, with $63 \%$ of Jewish respondents reporting that their father owned a business $(p<0.001)$, compared to $18 \%$ of non-Jewish respondents. The majority of lawyers in this study were born in the 1950s, growing up in Montreal in the postwar years during which the Jewish community became more prosperous, settling in to new suburban enclaves (Weinfeld 1980).

Confirming prior research on Montreal Jews, the data in Table 1 indicate that while living in Quebec these Jewish lawyers experienced greater social distance from French society than did nonJewish lawyers: almost all (95\%) Jewish respondents report their mother tongue as English, compared with $78 \%(p<0.001)$ of nonJews; they are also less likely to be highly proficient in French $(p<0.01)$. These Jewish lawyers maintained patterns of relative residential segregation in Montreal, with only $13 \%$ reporting that they lived in a predominantly Francophone community compared with more than half of the non-Jewish respondents $(p<0.001)$. And while the Jewish lawyers in this study completed both their undergraduate and law degrees in Montreal, attending universities where the majority of students are non-Jewish, they nonetheless maintained relatively isolated social relations. Compared to the non-Jewish lawyers in the sample, they were significantly less likely to work closely with Francophones $(p<0.01)$, to speak French regularly $(p<0.01)$, to socialize with Francophones $(p<0.001)$, or to study closely with Francophones $(p<0.01)$. This relative social 
isolation was coupled with uneasy social relations for Jewish respondents, with more than half of the Jewish lawyers reporting significantly higher levels of ethnic or racial discrimination $(p<0.001)$ and more than $60 \%$ of Jewish respondents reporting that they experienced religious discrimination $(p<0.001)$ while living in Quebec.

Given these differences between the Jewish and non-Jewish lawyers, it is perhaps not surprising that they also report different reasons for leaving Montreal. These are presented in Table 2. Jewish lawyers are more likely to report having moved because of political conditions $(p<0.001)$, the Quebec language laws $(p<0.001)$, not wanting to raise their children in Quebec $(p<0.01)$, and a desire to be amongst English-speakers $(p<0.01)$. However, they are less likely to report that their move was motivated to be closer to their spouse or family $(p<0.05)$, because of a job offer $(p<0.001)$, or simply for a change $(p<0.05)$. When asked why they chose to move to Ontario, Jewish lawyers are more likely to have expressed the desire to be among English-speakers $(p<0.01)$ and community members $(p<0.01) .{ }^{15}$

These motivations for migration are reinforced by numerous comments made by Jewish respondents to the survey, in which they express feeling like "second-class citizens" and having a "fear of persecution" while living in Quebec, and that while the decision to leave was "really all very sad," "the love affair is over," and "it had to be done, like pulling a rotten tooth." The comments of one Jewish respondent illustrate these sentiments:

I am extremely satisfied that I made the difficult decision to leave my family, friends and personal history behind me in Quebec. It was a gut-wrenching, very sad experience. I deeply missed the Montreal scene for years after. But, the sadness passed and I got what I wanted - the feeling of being an equal citizen with full rights instead of a second class citizen who is deeply resented by many Quebecois. I truly feel that I was "pushed out" of Quebec, a virtual refugee arriving in Toronto. Knowing very few people and starting a new life. I would never have left Quebec but for the constant negativity and resentment expressed against Quebecers of English-speaking heritage.

This pattern of responses suggests that for Jewish lawyers, the departure from Montreal was part of a larger political project of English-speaking outmigration that was experienced within the context of the social history of Jews in Quebec. Taken together,

${ }^{15}$ Other studies suggest a similar pattern. Weinfeld and Eaton (1979) found that 58\% of Jews would leave Quebec if the province attained sovereignty. The top three reasons for emigration were opposition to the Quebec government, the economic conditions in Quebec, and fear of Quebec separatism (Weinfeld \& Eaton 1979:67). 
these data highlight an important pattern: Jewish respondents were motivated to leave Montreal due to "push" factors, while nonJewish migration was motivated by "pull" factors away from the city.

\section{Jewish Lawyers, Social Capital, and Bounded Solidarity}

The data above suggest that these Jewish lawyers were part of an ethnic enclave in Montreal, experiencing distinct patterns of social and residential life in Quebec when compared with nonJewish respondents. When I combine these data with their shared experience of the political context of Quebec separatism that culminated in their outmigration from Montreal, I argue that they came to enjoy a "we-ness" that provided them with a form of social capital defined as "bounded solidarity." This solidarity emerges when an ethnic group, even if internally stratified, is faced with common adversities (Portes \& Sensenbrenner 1993:1324-5). This is an appropriable resource: as Dezalay describes in his analysis of Jewish financiers, lawyers, and accountants on Wall Street, " $[t]$ he strength of [their professional] networks derives from the social homogeneity of their members," and from their shared ethnicprofessional experience (1995b:82).

This form of social capital is, of course, well-known in the literature on ethnicity and immigration, and in the case of these Jewish lawyers emerges from their shared experiences, social background, and circumstances in Montreal (Portes \& Sensenbrenner 1993:1324). The survey data suggest that this bounded solidarity is maintained over time, with Jewish respondents retaining close ties to other former Quebeckers well after they have left the province. As indicated in Table 3, a majority of the Jewish lawyers report that more than a decade after their move from Montreal, at least half of their close friends are themselves originally from Montreal, a set of ties that is significantly $(p<0.01)$ stronger for Jewish compared to non-Jewish respondents. This

Table 3. Measures of Social Capital Before and After Migration From Quebec by Religious Identification

\begin{tabular}{lcc}
\hline & $\begin{array}{c}\text { All } \\
\text { Other }\end{array}$ \\
\hline $\begin{array}{l}\text { Joined or felt a sense of belonging to communities or voluntary } \\
\text { organizations in Quebec }\end{array}$ & $79.8 \%$ & $76.6 \%$ \\
$\begin{array}{l}\text { Moved to Ontario with spouse } \\
\text { Three or more of respondents' closest friends or family live in the }\end{array}$ & $47.5 \% * * * 23.6 \%$ \\
$\quad \begin{array}{l}\text { same city as them } \\
\text { Half, more than half, or all of respondent's close friends, who live in the } \\
\text { same city as them, are originally from Quebec }\end{array}$ & $58.8 \% * * * 37.6 \%$ \\
\hline
\end{tabular}

Tests of significance for Jewish respondents compared to non-Jewish respondents: ${ }^{*} p<0.05,{ }^{* *} p<0.01,{ }^{* * * *} p<0.001$ (two-tailed) 
pattern of connections is reinforced by the fact that when they left Montreal, Jewish respondents are more likely to have moved with their spouse $(p<0.001)$. It is important to stress, then, that the social capital drawn from this group's bounded solidarity has persisted over time, with Jewish lawyers' social ties enduring 10 , 15, or even 20 years after their move to Ontario. In the following two sections, I consider the ways in which this continued bounded solidarity and other forms of social capital play a pivotal role in legal careers.

\section{Mobilizing Social Capital in Legal Careers}

Social capital provides an important lens from which to understand lawyers' professional outcomes (see, e.g., Kay \& Hagan 1999), highlighting the ways in which individuals may be able to mobilize the capital available to them from a range of relationships. Yet as a multivalent concept, social capital is not easily captured through a single measure. As a result, this article draws on five measures of social capital in modeling a range of professional outcomes.

I begin by operationalizing two measures of social capital in the form of bounded solidarity (Portes \& Sensenbrenner 1993). The first measure of bounded solidarity is based on respondents' motivations for leaving Quebec. This is a dichotomous variable that is coded 1 if respondents report that they left Quebec for political reasons - namely, if they left Quebec because they did not want to raise children in the province or because of the language laws, political conditions, or race relations/ethnic tensions. This measure therefore reflects the extent to which respondents identify their move as part of a larger political project, one that evokes the sense of "we-ness" that is the hallmark of this form of social capital (Portes \& Sensenbrenner 1993); this measure is referred to as political-bounded solidarity. The second is a measure of the dense social networks from which bounded solidarity emerges, and it is based on the number of respondents' close friends currently living in the same city as them, who are originally from Quebec. This is captured as a dummy variable that equals 1 if respondents report that at least half of their friends living in the same city as them are originally from Quebec and 0 otherwise; this measure is referred to as friendship-bounded solidarity. Since the bivariate data indicate that Jewish respondents report significantly higher levels of this latter form of social capital, all models also include an interaction term that captures the intersection between this form of social capital and religious affiliation.

In addition to bounded solidarity, the analyses include measures of three additional forms of social capital, broadly derived 
from previous research on lawyer careers. The first measure reflects social capital as reciprocity exchanges, which "consist ... of the accumulation of 'chits' based on previous good deeds to others, backed by the norm of reciprocity" (Portes \& Sensenbrenner 1993:1324). This variable is based on the help received by respondents with their move to Ontario from someone already living in Ontario, such as finding a place to live, finding employment, making employment contacts, making social contacts, or help adjusting to their new surroundings. This is coded as a dummy variable equaling 1 if they had any such help, and 0 otherwise. The second measure of social capital captures the number of organizations or communities that respondents are presently a member of, or to which they feel a sense of belonging (e.g., Heinz, Schnoor et al. 2001; Kay \& Hagan 1999). The third measure focuses on more personal ties, measuring whether respondents report three or more close friends or family living in the same city as them.

\section{Social Capital and Practice Settings}

I begin by considering the distribution of respondents in various practice settings as a baseline model. Where lawyers work is one of the clearest markers of their income, status, clients, area of legal work, and prestige - from the high-paid elite lawyers working in mega-firms for corporations to the hardworking, lower-paid, solo practitioners working for individuals (Hagan et al. 1988; Heinz et al. 2005; Dinovitzer et al. 2004). And as the history of Jewish lawyers indicates, Jews have tended to be excluded from the profession's positions of power and prestige in large law firms.

Table 4 presents a simple distribution of respondents by practice setting and religious affiliation. This table, and all subsequent analyses, controls for cohort by distinguishing respondents who moved prior to 1980 compared with those who moved after 1980;

Table 4. Distribution of Respondents by Practice Setting, Religion, and Migrant Status for Two Cohorts

\begin{tabular}{|c|c|c|c|c|c|c|}
\hline & \multicolumn{3}{|c|}{ Moved After 1980} & \multicolumn{3}{|c|}{ Moved Before 1980} \\
\hline & Non-Jewish & Jewish & Total & Non-Jewish & Jewish & Total \\
\hline Not in Law & $15.3 \%$ & $13.5 \%$ & $14.7 \%$ & $17.1 \%$ & $17.2 \%$ & $17.1 \%$ \\
\hline Non-private practice & $43.1 \%$ & $21.6 \% *$ & $35.8 \%$ & $41.5 \%$ & $21.9 \% *$ & $29.5 \%$ \\
\hline Solo & $11.1 \%$ & $27.0 \% *$ & $16.5 \%$ & $12.2 \%$ & $26.6 \%$ & $21.0 \%$ \\
\hline Small firm (2-4) & $5.6 \%$ & $5.4 \%$ & $5.5 \%$ & $9.8 \%$ & $3.1 \%$ & $5.7 \%$ \\
\hline Mid-sized firm (5 thru 19) & $8.3 \%$ & $10.8 \%$ & $9.2 \%$ & $4.9 \%$ & $7.8 \%$ & $6.7 \%$ \\
\hline Large firm (20 and up) & $16.7 \%$ & $21.6 \%$ & $18.3 \%$ & $14.6 \%$ & $23.4 \%$ & $20.0 \%$ \\
\hline Total & $100 \%$ & $100 \%$ & $100 \%$ & $100 \%$ & $100 \%$ & $100 \%$ \\
\hline
\end{tabular}

Tests of significance for Jewish respondents compared to non-Jewish respondents within each cohort: ${ }^{*} p<0.05,{ }^{* * *} p<0.01,{ }^{* * * * *} p<0.001$ (two-tailed) 
this year marks the first Quebec referendum on sovereignty, with almost exactly half of the respondents leaving Montreal before this date, and half afterward. This provides a control for possible generational effects, since the respondents in this study moved over a 15-year period. The distribution in Table 4 indicates that Jewish lawyers in both cohorts are overrepresented in solo practice, with more than one-quarter of Jewish respondents working in this setting compared with only $11-12 \%$ of non-Jewish respondents $(p<0.05$ for the post-1980 cohort). Jewish lawyers in both cohorts are also significantly less likely $(p<0.05)$ to be working outside of private practice.

To better understand the mechanisms that underlie this pattern of Jewish overrepresentation in solo practice, I model the likelihood of working in solo practice, with $22 \%$ of all respondents working in this setting. ${ }^{16}$ Since the dependent variable is binary (coded as 1 if working in solo practice and 0 otherwise), I rely on logistic regression. In addition to the social capital variables described above, controls for demographic factors are also included. These include a dummy variable representing Jewish respondents and a dummy variable to control for gender, which prior research suggests is an important source of stratification in the legal profession (e.g., Hagan \& Kay 1995). Furthermore, since neither Jewish nor non-Jewish respondents work exclusively in the Greater Toronto Area (GTA) (46\% of non-Jewish respondents and 23\% of Jewish respondents work outside the GTA), all analyses include a variable that controls for whether they work inside or outside this area; variables and related descriptive statistics are displayed in Appendix A.

The first model, displayed in Table 5, controls only for religion and indicates that for Jewish respondents, the odds of working in solo practice increase by a factor of 2.5 compared with non-Jewish respondents $\left(b=0.91, e^{\mathrm{b}}=2.5 ; p<0.01\right)$. The second model adds the demographic and social capital variables, and indicates that the effect of being Jewish is no longer significant; instead, social capital in the form of reciprocity exchanges mitigates the likelihood of working in solo practice, decreasing the odds of working in this setting by $62 \%\left(b=-0.97, e^{\mathrm{b}}=0.38, p<0.05\right)$. This pattern suggests that the social capital that flows from an exchange of chits is a resource that can have beneficial and long-lasting effects. The final model includes an interaction term representing Jewish respondents and bounded solidarity in the form of continued friendships

16 According to the Law Society of Upper Canada's 2003 annual report, $16 \%$ of all members work in solo practice, and $24 \%$ of all employed members are solo practitioners. And solo practitioners comprise $74 \%$ of all those working in the private practice of law (Law Society of Upper Canada 2003). 


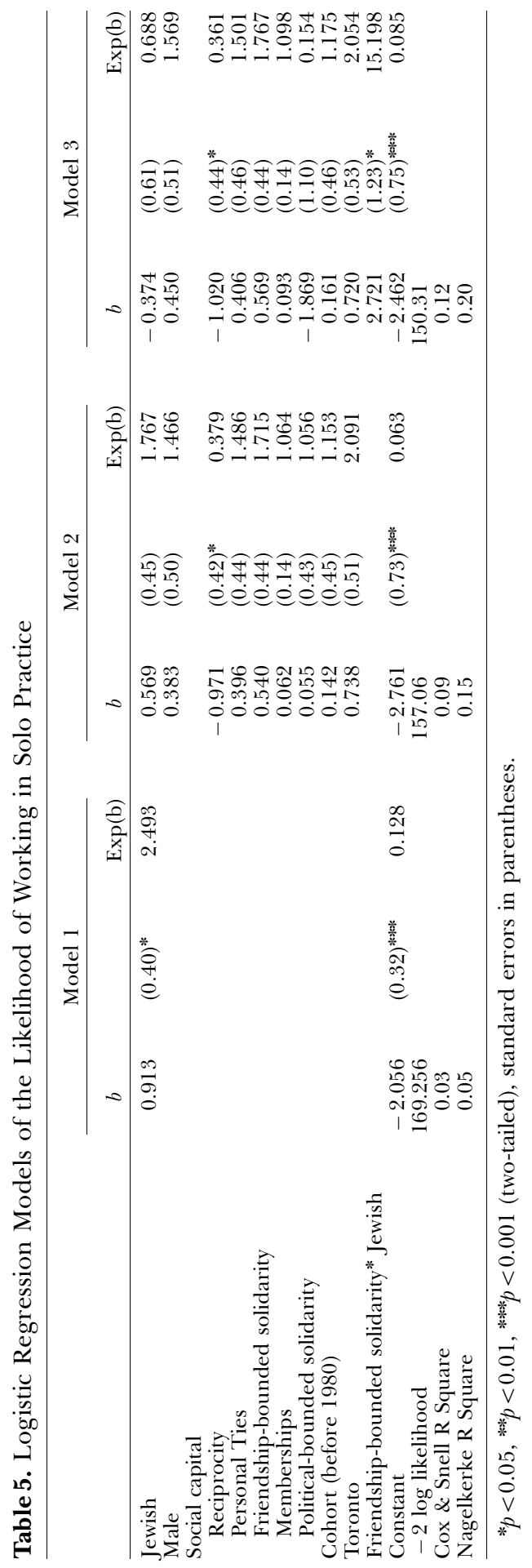


with co-migrants. The results indicate that the odds of working in solo practice for this particular group of Jewish respondents are 15 times greater than for Jewish respondents who do not have access to friendship-bounded solidarity $\left(b=2.72, e^{\mathrm{b}}=15.2 ; p<0.05\right)$. In this final model, there continues to be no direct effect for Jewish respondents, but the effect of reciprocity exchanges remains negative and significant $\left(b=-1.02, e^{\mathrm{b}}=0.36, p<0.05\right)$.

\section{Social Capital and Prestige of Practice}

I also investigate the determinants of prestige of field of law practiced, income, and job satisfaction by focusing on the 181 respondents who remain in the practice of law. The first analysis focuses on prestige of practice area, which has an important place in research on the legal profession. Distribution of prestige in the legal profession bears a close relationship with other aspects of its social organization and implicates the different values attributed to legal practice settings (Sandefur 2001). Prior research has examined the role of prestige of fields of law in understanding hierarchies within the profession (Sandefur 2001), including the distribution of legal services (Heinz \& Laumann 1994), income inequality (Hagan 1990), and the probability of partnership (Kay \& Hagan 1998, 1999). The measure of prestige is derived from Hagan (1990), in which Toronto lawyers reported the prestige of legal specializations, which were then ranked on a 10-point scale. As before, this model includes controls for religious affiliation, gender, cohort, and city of work, and now also includes a dummy variable coded as 1 to represent respondents working in solo practice.

The results are displayed in Table 6 . The first model predicting prestige of practice area indicates that working in solo practice results in a significant decrease in prestige $(b=-0.67, p<0.001)$, confirming prior research that solo practitioners' work often involves the less-prestigious cases of individual clients (Carlin 1994; Van Hoy 1993; Heinz \& Laumann 1994). The second model introduces the social capital variables and indicates a significant and negative effect for friendship-bounded solidarity $(b=-0.27$, $p<0.05)$. This finding suggests that respondents who report friendships with co-migrants are more likely to be working in areas of practice associated with lower levels of professional prestige; working in solo practice continues to have a negative and significant effect on prestige in this model $(b=-0.65, p<0.001)$. In the third model, the relationship between solo practice and prestige continues to be negative $(b=-0.56, p<0.001)$, while the interaction term representing Jewish respondents and friendship-bounded solidarity is negative and significant $(b=-0.58, p<0.05)$. This finding indicates that Jewish respondents who have maintained 
Table 6. OLS Regression Models of Prestige of Area of Law Practiced, Unstandardized Coefficients

\begin{tabular}{|c|c|c|c|}
\hline & Model 1 & Model 2 & Model 3 \\
\hline & $b$ & $b$ & $b$ \\
\hline Jewish & $-0.091(0.13)$ & $-0.065(0.14)$ & $0.205(0.18)$ \\
\hline Solo practice & $-0.667(0.15)^{* * * *}$ & $-0.648(0.16)^{* * * * *}$ & $-0.564(0.16)^{* * * * *}$ \\
\hline Age & $-0.010(0.01)$ & $-0.010(0.01)$ & $-0.012(0.01)$ \\
\hline Male & $0.055(0.13)$ & $0.112(0.14)$ & $0.087(0.14)$ \\
\hline \multicolumn{4}{|l|}{ Social capital } \\
\hline Political-bounded solidarity & & $-0.218(0.15)$ & $-0.217(0.15)$ \\
\hline Friendship-bounded solidarity & & $-0.270(0.13)^{*}$ & $0.017(0.18)$ \\
\hline Personal ties & & $0.118(0.14)$ & $0.099(0.14)$ \\
\hline Memberships & & $0.067(0.04)$ & $0.061(0.04)$ \\
\hline Reciprocity & & $0.077(0.13)$ & $0.085(0.13)$ \\
\hline Cohort (before 1980) & & $-0.064(0.16)$ & $-0.045(0.16)$ \\
\hline Toronto & & $0.011(0.13)$ & $0.004(0.13)$ \\
\hline Friendship-bounded solidarity* Jewish & & & $-0.578(0.25)^{*}$ \\
\hline (Constant) & $6.872(0.56)^{* * * *}$ & $6.750(0.68)^{* * * *}$ & $6.745(0.67)^{* * * * *}$ \\
\hline Adjusted $\mathrm{R}^{2}$ & 0.10 & 0.12 & 0.14 \\
\hline
\end{tabular}

${ }^{*} p<0.05,{ }^{* *} p<0.01, * * * p<0.001$ (two-tailed), standard errors in parentheses.

close ties to former Quebeckers tend to be working in fields of law with significantly lower levels of prestige.

\section{Social Capital and Job Satisfaction}

The next analysis examines the predictors of job satisfaction. As with prestige, job satisfaction can also be viewed as a stratification measure, with unequal distribution indicating possible inequality (Hull 1999). Studies have demonstrated the unequal distribution of job satisfaction across gender, practice setting, and income levels (Chambers 1989; Hagan \& Kay 1995; Heinz et al. 1999; Hull 1999; Kay 1997; Dau-Schmidt \& Mukhopadhaya 1999). In addition to the variables described earlier, therefore, this model includes additional demographic variables such as age and the presence of children, as well as work-related variables such as income, hours worked, and area of specialization. This analysis also includes four measures of work settings that reflect lawyers' formal status within the firm and the control and autonomy that lawyers feel they have over their work; these measures have been elaborated by Hagan et al.'s (1988) research on Canadian lawyers. The first measure is hierarchy, which represents the number of levels of individuals below the respondent (ranging from none to two) in the occupational structure. Second is the measure of authority, which indicates, on a four-point scale, the extent of authority the respondent has in relation to others in his or her workplace, ranging from (1) sanctioning authority (ability to reward or punish subordinates), (2) task authority (gives orders to subordinates), and (3) nominal supervision (supervises but does not sanction or give orders) to (4) no 
Table 7. OLS Regression Models of Job Satisfaction, Unstandardized Coefficients

\begin{tabular}{|c|c|c|c|}
\hline & Model 1 & Model 2 & Model 3 \\
\hline & $b$ & $b$ & $b$ \\
\hline Jewish & $-0.522(0.56)$ & $-0.492(0.57)$ & $-1.488(0.74)^{*}$ \\
\hline Male & $-0.024(0.61)$ & $-0.219(0.61)$ & $-0.074(0.61)$ \\
\hline Age & $-0.065(0.06)$ & $-0.029(0.06)$ & $-0.024(0.06)$ \\
\hline Married & $0.579(0.79)$ & $0.940(0.78)$ & $0.949(0.77)$ \\
\hline \multirow{2}{*}{\multicolumn{4}{|c|}{ Practice settings ${ }^{1}$}} \\
\hline & & & \\
\hline Solo practitioner & $-0.439(1.03)$ & $-0.421(1.00)$ & $-0.727(1.00)$ \\
\hline Small firm & $1.432(1.29)$ & $1.846(1.26)$ & $1.830(1.25)$ \\
\hline Mid-sized firm & $-0.589(1.11)$ & $-1.135(1.10)$ & $-1.412(1.10)$ \\
\hline Non-private practice & $1.683(0.84)^{*}$ & $1.311(0.83)$ & $1.337(0.82)$ \\
\hline \multicolumn{4}{|l|}{ Aspects of work settings } \\
\hline Hierarchy & $0.922(0.61)$ & $1.194(0.60)^{*}$ & $1.127(0.60)$ \\
\hline Authority & $-0.438(0.39)$ & $-0.465(0.38)$ & $-0.414(0.37)$ \\
\hline Autonomy & $0.559(0.33)$ & $0.691(0.32)^{*}$ & $0.644(0.32)^{*}$ \\
\hline Decisionmaking & $0.448(0.24)$ & $0.336(0.24)$ & $0.323(0.24)$ \\
\hline Hours worked & $-0.029(0.02)$ & $-0.025(0.02)$ & $-0.030(0.02)$ \\
\hline Specialization status & $0.588(0.33)$ & $0.661(0.33)^{*}$ & $0.773(0.33)^{*}$ \\
\hline Income (000’s) & $0.008(0.00)$ & $0.007(0.00)$ & $0.007(0.00)$ \\
\hline \multicolumn{4}{|l|}{ Social capital } \\
\hline Political-bounded solidarity & & $-0.498(0.61)$ & $-0.491(0.61)$ \\
\hline Friendship-bounded solidarity & & $1.618(0.56)^{* * *}$ & $0.554(0.75)$ \\
\hline Memberships & & $0.179(0.18)$ & $0.196(0.18)$ \\
\hline Personal ties & & $0.591(0.57)$ & $0.654(0.56)$ \\
\hline Reciprocity & & $-0.379(0.55)$ & $-0.398(0.54)$ \\
\hline Cohort (before 1980) & & $-0.879(0.66)$ & $-0.936(0.66)$ \\
\hline Toronto & & $-1.093(0.58)$ & $-1.073(0.58)^{*}$ \\
\hline Friendship-bounded solidarity* Jewish & & & $2.217(1.07)^{*}$ \\
\hline (Constant) & $15.236(4.05)^{\text {*****k }}$ & $13.084(4.42)^{* * *}$ & $12.810(4.38)^{* * *}$ \\
\hline Adjusted $R^{2}$ & 0.12 & 0.17 & 0.19 \\
\hline
\end{tabular}

$* p<0.05, * * p<0.01, * * * *<<0.001$ (two-tailed), standard errors in parentheses.

${ }^{1}$ Excluded category is large firms.

supervisory responsibility (does not supervise anyone). The third measure is lawyers' autonomy, which indicates whether respondents design no, a few, some, all, or most aspects of their work, and whether they put these ideas into practice. The final measure represents respondents' decisionmaking, which indicates on a five-point scale the extent of respondents' participation in decisionmaking in their setting.

The dependent variable, job satisfaction, is an index comprising respondents' answers to five questions (on a five-point Likert scale): How satisfied are you with your job; Would you recommend your job to a friend; Given a choice, would you take the same job again; How does your current job compare to the sort of job you wanted when you took it; and How satisfied are you with the way your job allows you to mix work and your personal life. The items are summed to form a scale ranging from five to 25 , with an alpha reliability score of 0.83 .

In the first model displayed in Table 7, the data indicate that lawyers working outside of private practice express higher levels of 
job satisfaction than their large-firm counterparts $(b=1.68$, $p<0.05$ ), but there is no significant effect for Jewish respondents or for the work-related variables. The second model introduces the social capital variables and indicates that friendship-bounded solidarity is a positive predictor of job satisfaction $(b=1.62, p<0.01)$. Echoing prior research (Hagan et al. 1988; Hull 1999), the second model finds that key aspects of lawyers' work settings - their hierarchy $(b=1.19, p<0.05)$ and autonomy $(b=0.69, p<0.05)$-are positively related to satisfaction, and that respondents working in more-prestigious practice areas are also more satisfied with their jobs $(b=0.66, p<0.05)$. The third and final model includes the interaction term for Jewish respondents who report that at least half of their close friends are former Quebeckers. The data indicate that this group of respondents reports higher levels of job satisfaction, suggesting a unique payoff to the friendship connections that they have maintained over time $(b=2.22, p<0.05)$. The data also continue to demonstrate that autonomy and specialization remain positive predictors of satisfaction, though the positive effect of hierarchy is no longer significant. In this final model, the coefficient for the main effect of Jewish respondents is negative and significant $(b=-1.49, p<0.05)$, suggesting lower levels of job satisfaction for Jewish respondents; similarly, respondents working in the GTA express lower levels of job satisfaction $(b=-1.07$, $p<0.05$ ), suggesting that working life in the country's largest city carries with it a unique set of costs.

\section{Social Capital and Income}

Finally, I consider the predictors of income drawing on the same set of variables used above; however, the variable for age is replaced with number of years since bar admission, since seniority in legal practice is a more direct measure of progression in one's career rather than age. The first model in Table 8 finds no significant difference in the earnings of men and women, while the number of years of seniority is a positive and significant predictor of income $(b=2.23, p<0.01)$, with the financial payoffs to legal careers increasing over time. The data also demonstrate that compared to lawyers working in large private firms, lawyers in all other settings are earning significantly less - a gap of $\$ 95,000$ for those in solo practice $(p<0.001), \$ 125,000$ for those in small firms $(p<0.001), \$ 84,000$ for those in mid-sized firms $(p<0.001)$, and $\$ 100,000$ for those working outside of private practice $(p<0.001)$. As might be expected, this first model also indicates that working in a more-prestigious area of law also significantly increases income $(b=17.19, p<0.01)$. The second model, which includes the social capital variables, indicates that social capital has no direct effects on 
Table 8. OLS Regression Models of Income (in 1,000's), Unstandardized Coefficients

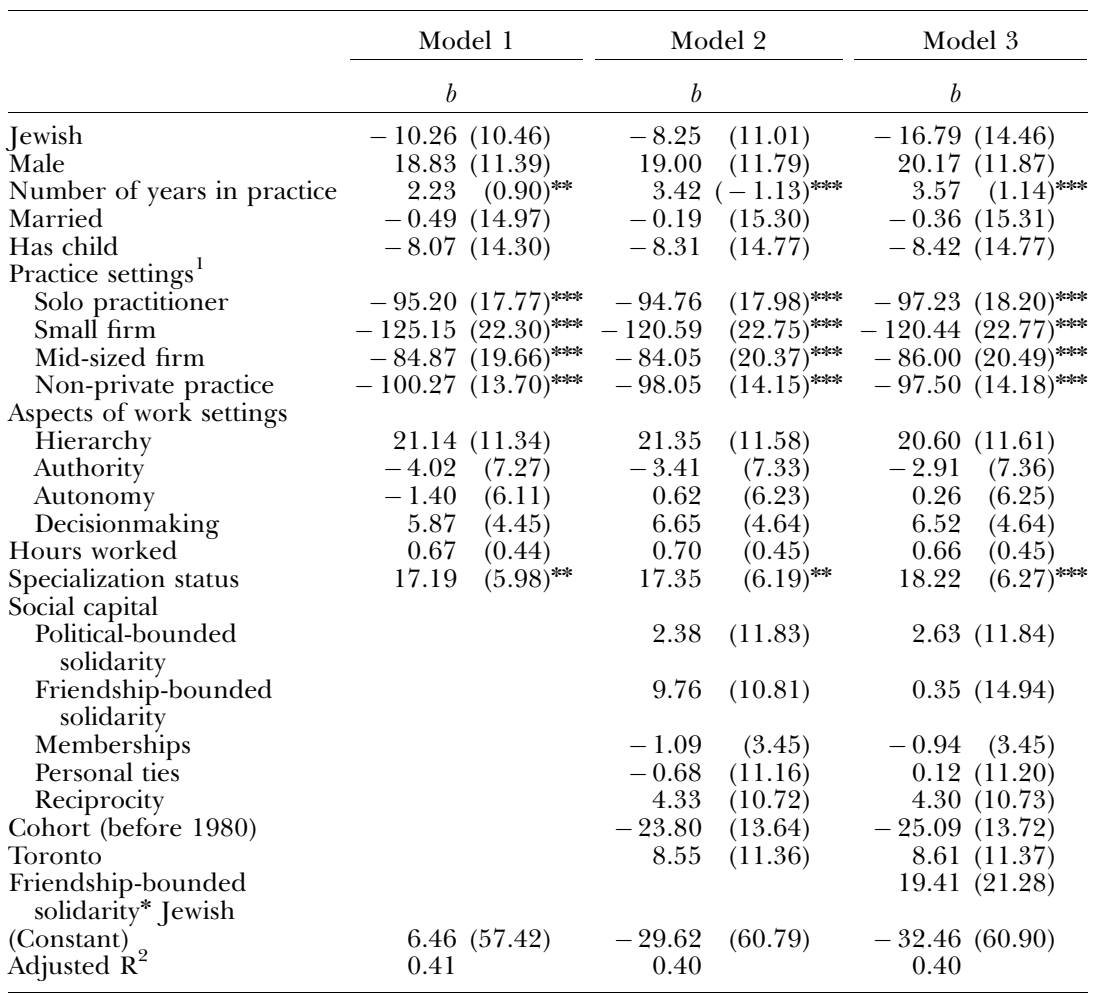

${ }^{*} p<0.05,{ }^{* * *} p<0.01,{ }^{* * * *} p<0.001$ (two-tailed), standard errors in parentheses.

${ }^{1}$ Excluded category is large firms.

income. And in contrast to the job satisfaction model, which indicates higher levels of satisfaction for Jewish lawyers who have maintained friendships with former Quebeckers, the third model in Table 8 shows no significant effect for this interaction. Finally, the income regressions show no significant financial payoff for working in the GTA, net of the other variables in the model. ${ }^{17}$

\section{Summary}

The strategy in the above analyses was to explore the career outcomes for Jewish lawyers - a group that has been traditionally

17 This is a robust pattern of findings. In supplemental analyses, I restricted the sample to lawyers working in the Toronto area, and the same patterns emerged with respect to religious affiliation and friendship-bounded solidarity. Within this subsample, Jewish lawyers remain more likely to work as solo practitioners, as are Jewish lawyers with friendship-bounded solidarity. Furthermore, religious affiliation and friendship-bounded solidarity, as well as the interaction of these two, continue to have the same relationship (in sign and significance) to prestige of field of practice, income, and job satisfaction. 
disadvantaged in the legal profession - with a particular focus on the role of social capital. And I find that in building legal careers, the Jewish lawyers in this study have derived both professional advantages and disadvantages through social capital, leading to a unique structural position within the bar.

The initial models find that Jewish lawyers continue to be more likely to be working as solo practitioners. Yet they also demonstrate that reciprocity exchanges, a form of social capital generated through the accumulation of chits (Portes \& Sensenbrenner 1993), reconfigures the playing field; and once this form of social capital is accounted for, there is no longer a significant difference in whether Jewish or non-Jewish lawyers are working in solo practice. The persistence of an ethnic bar, therefore, is mitigated through this particular form of social capital-so that we gain analytical purchase on how Jewish lawyers may enter more elite positions within the profession.

But attention to different forms of social capital provides us with greater nuance on the position of Jewish lawyers within the bar. For Jewish lawyers who enjoy friendship-bounded solidarity, a form of social capital that is central to understanding the context of ethnic professionals (Dezalay 1995b; Portes \& Sensenbrenner 1993), the outcomes are less positive: these lawyers are 15 times more likely to be working in solo practice, and even beyond solo practice are more likely to be working in lessprestigious fields of specialization. In this study, the evidence suggests that even for lawyers with elite credentials, bounded solidarity cannot always be converted into positive professional outcomes. Dense ties, then, can engender social and professional costs, echoing recent research on ethnic economies (Waldinger 1997; Fong \& Ooka 2002; Ooka \& Wellman, forthcoming). These findings resonate with research on Catholic lawyers in Chicago, whose strong ethno-religious ties in particular local law schools and in Democratic Party politics have promoted a strong path to legal careers in government or within the personal injury bar (Parikh \& Garth 2005:276).

Yet if the lens is shifted somewhat, this same form of social capital - friendship-bounded solidarity - is found to have a positive effect on other professional outcomes. While Jewish lawyers in this study report lower levels of job satisfaction, social capital can provide an alternative professional experience: those Jewish lawyers who enjoy bounded solidarity in the form of friendship ties enjoy higher levels of job satisfaction, despite their lower levels of prestige within the professional hierarchy. 


\section{Conclusion}

Although social capital has been mobilized to represent a variety of resources that are available to individuals, the concept as initially deployed by Bourdieu is geared toward providing a structural account of the reasons some succeed, while others fail. Social capital, according to Bourdieu, fits within a broader conceptualization of the importance of capital, which he understands as the basis for all social relations:

[Capital] is what makes the games of society - not least, the economic game - something other than simple games of chance offering at every moment the possibility of a miracle. Roulette, which holds out the opportunity of winning a lot of money in a short space of time, and therefore capable of changing one's social status quasi-instantaneously, and in which the winning of the previous spin of the wheel can be staked and lost at every new spin, gives a fairly accurate image of this imaginary universe of perfect competition or perfect equality of opportunity, a world without inertia, without accumulation, without heredity or acquired properties, in which every moment is perfectly independent of the previous one ... so that at each moment anyone can become anything. Capital ... is a force inscribed in the objectivity of things so that everything is not equally possible or impossible (Bourdieu 1986:241-2; emphasis added, internal footnotes omitted).

Bourdieu (1986) emphasizes that the various forms of capital are related to the objective positions people occupy in social life and the dispositions that they hold (see also Lin 2000; on positions and dispositions, see Bourdieu 2004:34-5) — as is people's ability to convert their capital into a meaningful resource.

Taking a Bourdieusian formulation of social capital as the starting point, this article has explored the role of social capital in the career trajectories of Jewish lawyers. I find that Jewish lawyers who navigate their careers away from the least prestigious settings are helped along this trajectory by a form of social capital that resides in networks based on exchanges of chits. On the other hand, the path of Jewish lawyers into lower-prestige positions such as solo practice is strongly influenced by embeddedness within a smaller, more dense social network. Taken together, these represent an analog to Granovetter's emphasis on "weak ties" (Granovetter 1974), and the importance of a nuanced approach to understanding the role of capital in building careers. The positions that lawyers take up in the profession can be understood, then, through a perspective that focuses on the structure of the distribution of social capital and the constraints and opportunities this makes available (see, e.g., Bourdieu 1993, 2004:32-7, 55-62; Dezalay \& Garth 1996). 


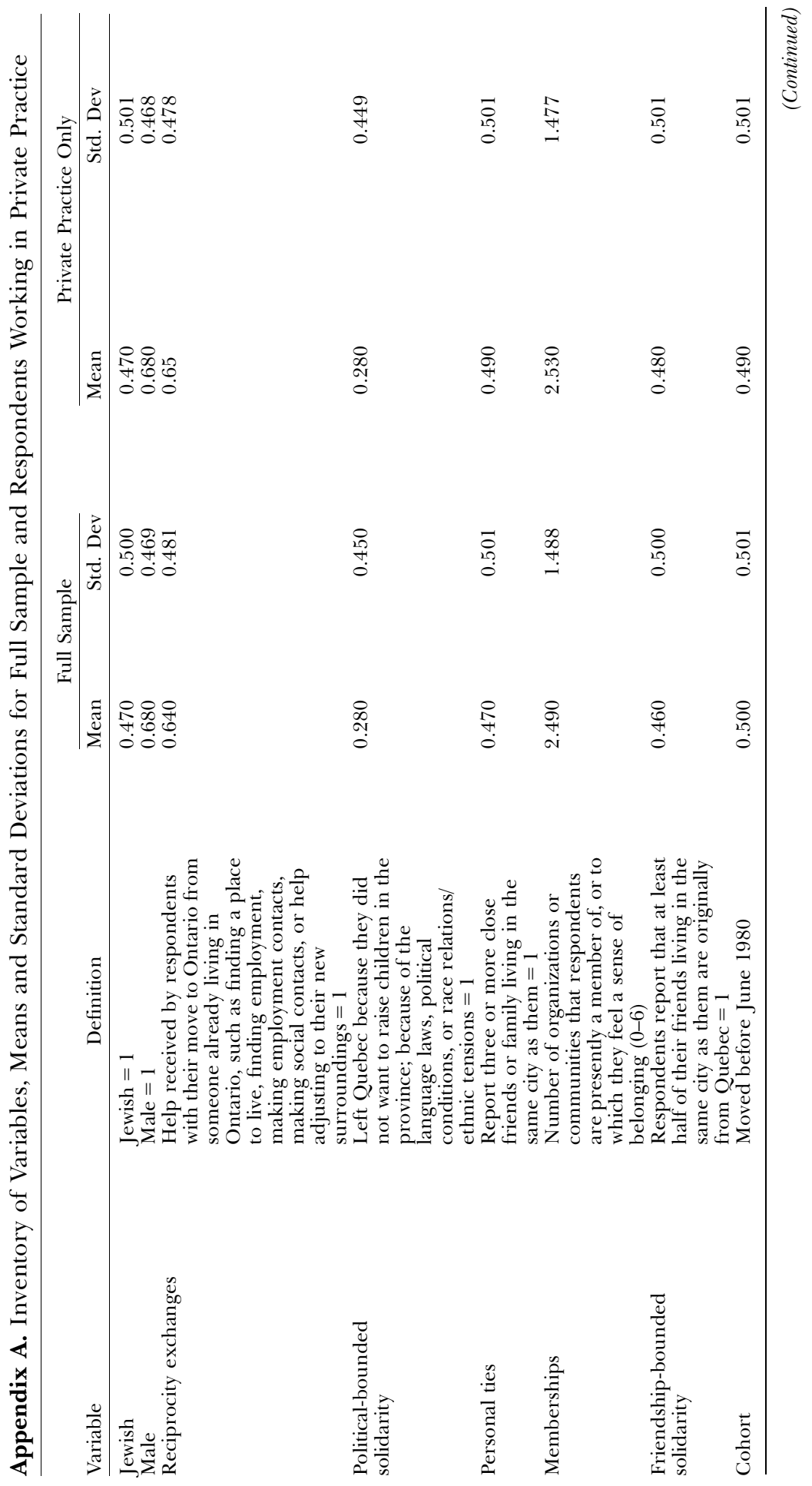




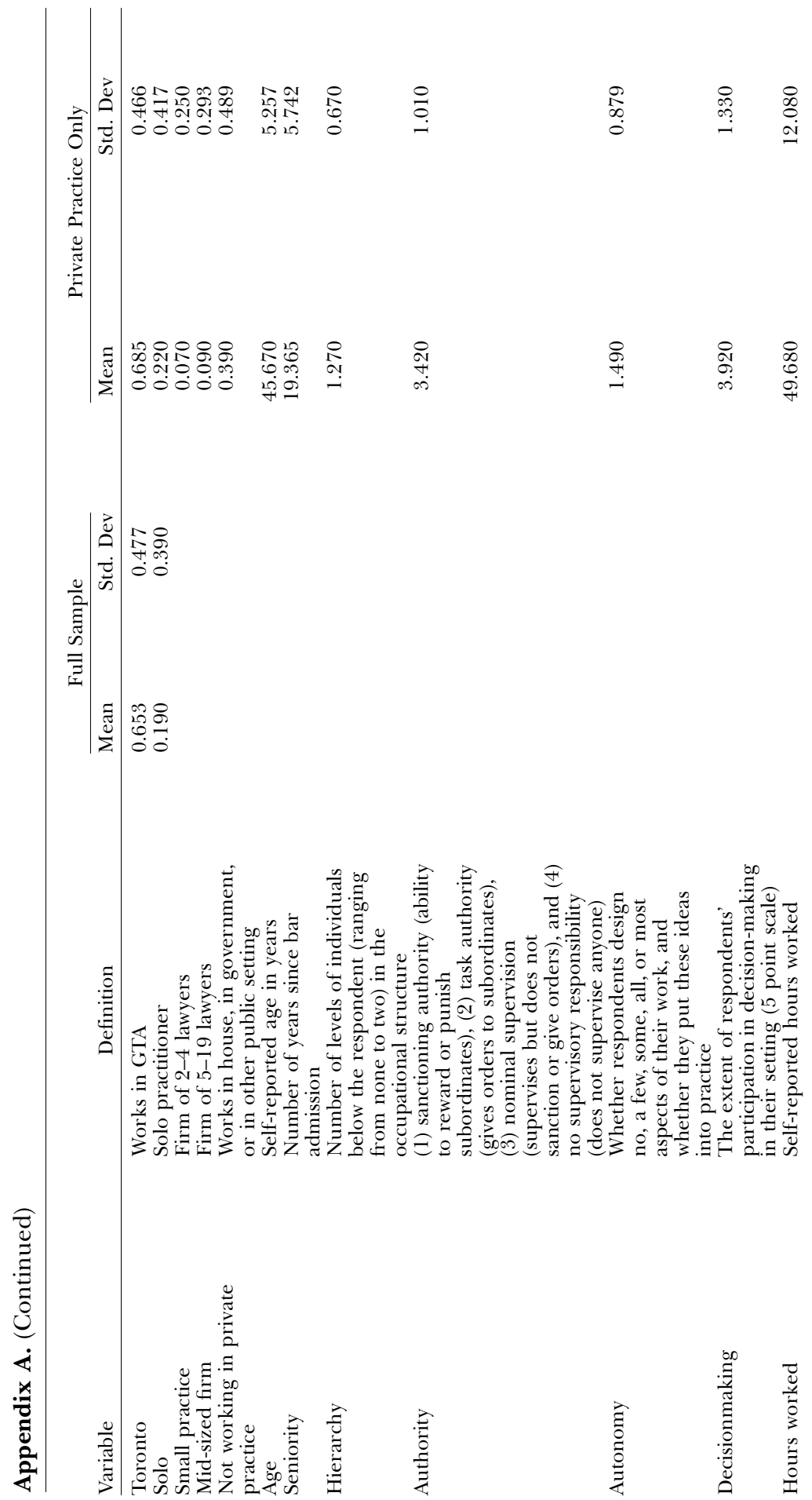




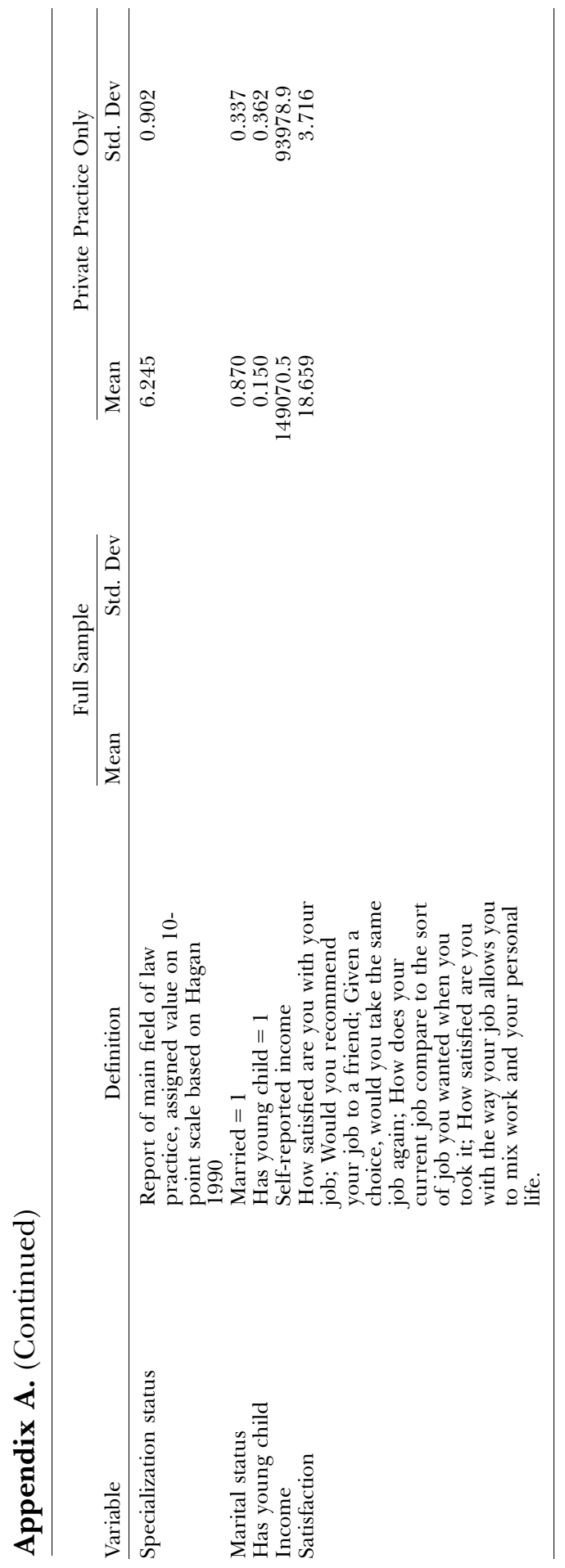


By relying on social capital as a main analytic focus, we are better able to understand the position of Jewish lawyers in the legal profession more generally. The data in this article suggest that the path into less-prestigious practice settings, such as solo practiceand the continued ethnic stratification of the bar (see also Heinz et al. 2005)-relates to a complex hierarchization in which ascriptive characteristics intersect with opportunity structures that value specific credentials, social and professional networks, and social backgrounds. In this way, the findings in this article speak to the broader question of how different groups fare in the legal profession, and to the role of social networks in maintaining cleavages within the bar. As Wilkins' $(1999,2004)$ research demonstrates, a persistent barrier for black lawyers in corporate firms, both in the tournament to partnership (Galanter \& Palay 1991) and beyond, is a lack of access to the social networks providing the mentoring, clients, referrals, work assignments, and support that promote success within these settings. Kay and Hagan's (2003) work also indicates that women are denied access to the social networks within law firms and are more likely to be excluded from working on important files, thereby contributing to the exodus of women from law firms.

Similarly, the present findings indicate that to understand how the rewards of the legal profession are structured we cannot assume that the more capital individuals have, the better they will do. This study finds that disadvantaged groups do not merely have "less" capital-and therefore remedies to inequality should not simply ensure that individuals receive equal access to capital in all its forms (see also Garth 2004). As Bourdieu (1986) cautions in the quote above, "everything is not equally possible or impossible." This perspective allows us to move beyond a simple cataloguing of assets and provides us with a lens from which to understand the intersection of people's social position, their accumulated capital, and whether they have the resources to transform this capital as they build their legal careers.

\section{References}

Arnold, Janice (2005) “Moderate Growth Projected for Canadian Jewry," The Canadian Jewish News, April 7. http://www.cjnews.com/viewarticle.asp?id=6050\&s=1 (accessed 18 April 2005).

Arthurs, Harry (1996) "Lawyering in Canada in the $21^{\text {st }}$ Century," 15 Windsor Yearbook of Access to Justice 202-25.

—_ e et al. (1971) "The Toronto Legal Profession: An Exploratory Survey," 21 University of Toronto Law J. 498-528. 
Auerbach, Jerold S. (1977) Unequal Justice: Lawyers and Social Change in Modern America. New York: Oxford Univ. Press.

Bailey, Thomas, \& Roger Waldinger (1991) "Primary, Secondary, and Enclave Labor Markets: A Training System Approach," 56 American Sociological Rev. 432-45.

Belanger, Chabot, et al. (1968) Les Avocats du Quebec: Etude Socio-economique. Montreal: Cadres Professionals.

Bourdieu, Pierre (1977) Outline of a Theory of Practice. Cambridge, UK: Cambridge Univ. Press.

—_ (1986) "The Forms of Capital," in J. G. Richardson, ed., Handbook of Theory and research for the sociology of education. Westport, CT: Greenwood Press.

— (1993) The Field of Cultural Production: Essays on Art and Literature. Cambridge, United Kingdom: Polity Press.

- (2004) Science of Science and Reflexivity. Cambridge, United Kingdom: Polity Press.

Bourgois, Philippe (1995) In Search of Respect: Selling Crack in El Barrio. New York: Cambridge Univ. Press.

Breton, Raymond (1964) "Institutional Completeness of Ethnic Communities and the Personal Relations of Immigrants," 70 American J. of Sociology 193-205.

Brodbar-Nemzer, Jay, et al. (1993) "An Overview of the Canadian Jewish Community," in R. J. Brym et al., eds., The Jews in Canada. Toronto: Oxford Univ. Press.

Brown, Michael (1986) Jew or Juif? Jews, French Canadians, and Anglo-Canadians, 17591914. Philadelphia: The Jewish Publication Society.

Calhoun, Craig (2003) "Pierre Bourdieu," in G. Ritzer, ed., The Blackwell Companion to Major Contemporary Social Theorists. Oxford, United Kingdom: Blackwell.

Carlin, Jerome E. (1966) Lawyers' Ethics: A Survey of the New York City Bar. New York: Russell Sage Foundation.

—_ (1994) Lawyers on Their Own: The Solo Practitioner in an Urban Setting. San Francisco: Austin \& Winfield.

Chambers, David L. (1989) "Accommodation and Satisfaction: Women and Men Lawyers and the Balance of Work and Family," 14 Law and Social Inquiry 251-87.

Cole, Curtis (1996) "A Family Firm in Transition: Osler, Hoskin, and Harcourt in the 1950s and 1960s," in C. Wilton, ed., Essays in the History of Canadian Law. Toronto: Osgoode Society.

Coleman, James S. (1988) "Social Capital in the Creation of Human Capital," 94 American J. of Sociology S95-S120.

Daniels, Ron (1993) "Growing Pains: The Why and How of Canadian Law Firm Expansion," 43 University of Toronto Law J. 147-206.

Dau-Schmidt, Kenneth G., \& Kaushik Mukhopadhaya (1999) "The Fruits of Our Labors: An Empirical Study of the Distribution of Income and Job Satisfaction Across the Legal Profession," $49 \mathrm{~J}$. of Legal Education 342-66.

Delisle, Esther (1993) The Traitor and the Jew. Montreal: Robert Davies Publishing.

Dezalay, Yves (1995a) "Introduction: Professional Competition and the Social Construction of Transnational Markets," in Y. Dezalay \& D. Sugarman, eds., Professional Competition and Professional Power: Lawyers, Accountants and the Social Construction of Markets. London: Routledge.

- (1995b) "Technological Warfare: The Battle to Control the Mergers and Acquisition Market in Europe," in Y. Dezalay \& D. Sugarman, eds., Professional Competition and Professional Power: Lawyers, Accountants and the Social Construction of Markets. London: Routledge.

Dezalay, Yves, \& Bryant G. Garth (1996) Dealing in Virtue: International Commercial Arbitration and the Construction of a Transnational Legal Order. Chicago: Univ. of Chicago Press.

Dinovitzer, Ronit, et al. (2003) "Choice and Circumstance: Social Capital and Planful Competence in the Attainments of Immigrant Youth," 28 The Canadian J. of Sociology 463. 
(2004) "After the JD: First Results of a National Study of Legal Careers," American Bar Foundation and NALP. http://abfn.org/ajd.pdf (accessed 28 Sept. 2005).

Dixon, Jo, \& Carroll Seron (1995) "Stratification in the Legal Profession: Sex, Sector and Salary," 29 Law E Society Rev. 381-412.

Doeringer, Peter, \& Phillip Moss (1986) "Capitalism and Kinship: Do Institutions Matter in the Labor Market?," 40 Industrial Labor Relations Rev. 48-55.

Erlanger, Howard S. (1980) "The Allocation of Status within Occupations: The Case of the Legal Profession," 58 Social Forces 882-903.

Fong, Eric F., \& Emi Ooka (2002) "The Social Consequences of Participating in the Ethnic Economy," 36 International Migration Rev. 125-46.

Fordham, Signithia, \& John U. Ogbu (1986) "Black Students' School Success: Coping with the Burden of 'Acting White," 18 Urban Rev. 176-206.

Galanter, Marc, \& Thomas Palay (1991) Tournament of Lawyers: The Transformation of the Big Law Firm. Chicago: Univ. of Chicago Press.

Garth, Bryant G. (2004) "Noblesse Oblige as an Alternative Career Strategy," 41 Houston Law Rev. 93-111.

Geertz, Clifford (1963) Peddlers and Princes. Chicago: Univ. of Chicago Press.

Granovetter, Mark S. (1974) Getting a Job: A Study of Contacts and Careers. Cambridge, MA: Harvard Univ. Press.

Greeley, Andrew (1997) "Coleman Revisited: Religious Structures as a Source of Social Capital," 40 American Behavioral Scientist 587-94.

Hagan, John (1990) "The Gender Stratification of Income Inequality among Lawyers," 68 Social Forces 835-55.

Hagan, John, \& Fiona Kay (1995) Gender in Practice: A Study of Lawyers' Lives. New York: Oxford Univ. Press.

Hagan, John, et al. (1988) "Class Structure and Legal Practice: Inequality and Mobility among Toronto Lawyers," 22 Law \& Society Rev. 9-55.

Halliday, Terrance C. (1986) "Six Score Years and Ten: Demographic Transitions in the American Legal Profession, 1850-1980," 20 Law E Society Rev. 53-78.

Halliday, Terence C., \& Lucien Karpik (1998) Lawyers and the Rise of Western Political Liberalism: Europe and North America from the Eighteenth to Twentieth Centuries. Oxford, UK: Oxford Univ. Press.

Heinz, John P., \& Edward O. Laumann (1994) Chicago Lawyers: The Social Structure of the Bar. New York: Russell Sage Foundation and American Bar Foundation.

Heinz, John P., et al. (1999) "Lawyers and Their Discontents: Findings from a Survey of the Chicago Bar," 74 Indiana Law J. 735-58.

Heinz, John P., \& Paul Schnoor, et al. (2001) "Lawyers' Roles in Voluntary Associations: Declining Social Capital?," 26 Law E Social Inquiry 597-629.

Heinz, John P., \& Robert L. Nelson, et al. (2001) "The Scale of Justice: Observations on the Transformation of Urban Law Practice," 27 Annual Rev. of Sociology 337-62.

Heinz, John P., et al. (2005) Urban Lawyers: The New Social Structure of the Bar. Chicago: Univ. of Chicago Press.

Hull, Kathleen E. (1999) "The Paradox of the Contented Female Lawyer," 33 Law छ Society Rev. 687-702.

Jedwab, Jack (1995) "The Politics of Dialogue: Rapprochement Efforts Between Jews and French-Canadians 1939-1960," in I. Robinson \& M. Butovsky, eds., Renewing Our Days: Montreal Jews in the Twentieth Century. Montreal: Vehicule Press.

- (1996) English in Montreal: A Layman's Look at the Current Situation. Montreal: Les Editions Images.

Kay, Fiona M. (1997) "Flight from Law: A Competing Risks Model of Departures from Law Firms," 31 Law \& Society Rev. 301-35.

Kay, Fiona M., \& John Hagan (1998) "Raising the Bar: The Gender Stratification of Law-Firm Capital," 63 American Sociological Rev. 728-43. 
(1999) "Cultivating Clients in the Competition for Partnership: Gender and the Organizational Restructuring of Law Firms in the 1990s," 33 Law E Society Rev. $517-55$.

(2003) "Building Trust: Social Capital, Distributive Justice, and Loyalty to the Firm," 28 Law E Social Inquiry 483-519.

Ladinsky, Jack (1963) "Careers of Lawyers, Law Practice and Legal Institutions," 28 American Sociological Rev. 47-54.

Langlais, Jacques, \& David Rome (1991) Jews \& French Quebecers. Waterloo, Ontario: Wilfrid Laurier Univ. Press.

Law Society of Upper Canada (2003) “Annual Report,” http://www.lsuc.on.ca/news/pdf/ arep_full03.pdf (accessed 28 Sept. 2005).

Lena, Hugh F., et al. (1993) "Professional Status at Midcareer: The Influence of Social and Academic Origins on Lawyers' Achievement," 8 Sociological Forum 365-82.

Light, Ivan H., \& Edna Bonacich (1988) Immigrant Entrepreneurs: Koreans in Los Angeles, 1965-1982. Berkeley: Univ. of California Press.

Lin, Nan (2000) "Inequality in Social Capital," 29 Contemporary Sociology 785-95.

MacLennan, Hugh (1957) Two Solitudes. Toronto: Macmillan of Canada.

Maheu, Robert (1983) "Lémigration Des Anglophones Québécois," 12 Cahiers Quebécois de Démographie 272-9.

Nee, Victor G., \& Brett De Bary Nee (1974) Longtime California, a Documentary Study of an American Chinatown. Boston: Houghton Mifflin.

Nee, Victor, et al. (1994) "Job Transitions in an Immigrant Metropolis-Ethnic Boundaries and the Mixed Economy," 59 American Sociological Rev. 849.

Nelson, Robert L. (1994) "The Futures of American Lawyers: A Demographic Profile of a Changing Profession in a Changing Society," 44 Case Western Reserve Law Rev. 345-406.

Nigro, Mario, \& Clare Mauro (1999) "The Jewish Immigrant Experience and the Practice of Law in Montreal, 1830 to 1990," 44 McGill Law J. 999-1046.

Norris, Alexander (1999) "Happy to Be Here: Anglos with Non-British Roots are the Ones More Likely to Stay in Quebec-As Are Those Who've Learned French," Montreal Gazette, 30 May, p. A1.

Ooka, Emi, \& Barry Wellman (forthcoming) "Does Social Capital Pay Off More Within or Between Ethnic Groups? Analyzing Job Searchers in Five Toronto Ethnic Groups," in E. Fong, ed., Inside the Mosaic. Toronto: Univ. of Toronto Press.

Parikh, Sara, \& Bryant Garth (2005) "Philip Corboy and the Construction of the Plaintiffs' Personal Injury Bar," 30 Law \& Social Inquiry 269-304.

Portes, Alejandro (1998) "Social Capital: Its Origins and Applications in Modern Sociology," 24 Annual Rev. of Sociology 1-24.

Portes, Alejandro, \& Julia Sensenbrenner (1993) "Embeddedness and Immigration: Notes on the Social Determinants of Economic Action," 98 American J. of Sociology 1320-50.

Ram, Bali, et al. (1994) Canadians on the Move. Ottawa: Statistics Canada.

Reichman, Nancy J., \& Joyce S. Sterling (2002) "Recasting the Brass Ring: Deconstructing and Reconstructing Workplace Opportunities for Women Lawyers," 29 Capital University Law Rev. 923-77.

Regehr, Ted D. (1996) "Elite Relationships, Partnership Arrangements, and Nepotism at Blakes, a Toronto Law Firm, 1858-1924," in C. Wilton, ed., Essays in the History of Canadian Law. Toronto: Osgoode Society.

Richler, Mordecai (1961) "Their Canada and Mine: A Memoir," 32 Commentary 135-43.

Robinson, Ira, \& Mervin Butovsky (1995) Renewing Our Days: Montreal Jews in the Twentieth Century. Montreal: Vehicule Press.

Robson, Karen, \& Jean E. Wallace (2001) “Gendered Inequalities in Earnings: A Study of Canadian Lawyers," 38 Canadian Rev. of Sociology and Anthropology 75-95. 
Rosenberg, Michael M., \& Jack Jedwab (1992) "Institutional Completeness, Ethnic Organizational Style and the Role of the State: Jewish, Italian and Greek Communities of Montreal," 29 Canadian Rev. of Sociology and Anthropology 266-87.

Rudin, Ronald (1986) Histoire du Quebec Anglophone 1759-1980. Quebec: Institut Quebecois de Recherche sur la Culture.

Sandefur, Rebecca L. (2001) "Work and Honor in the Law: Prestige and the Division of Lawyers' Labor,” 66 American Sociological Rev. 382.

Shahar, Charles (2003) "2001 Census Analysis Series: The Jewish Community of Montreal," Federation CJA, Montreal. http://www.federationcja.org/campaign/download/demographics/census 1-basic.pdf (accessed 18 April 2005).

Shamir, Ronen (1995) Managing Legal Uncertainty: Elite Lawyers in the New Deal. Durham, NC: Duke Univ. Press.

Silberman, Charles E. (1985) A Certain People: American Jews and Their Lives Today. New York: Summit Books.

Sniderman, Paul M., et al. (1993) "Psychological and Cultural Foundations of Prejudice: The Case of Anti-Semitism in Quebec," 30 Canadian Rev. of Sociology and Anthropology 242-70.

Stanton-Salazar, Ricardo D., \& Sanford M. Dornbusch (1995) "Social Capital and the Reproduction of Inequality: Information Networks among Mexican-Origin High School Students," 68 Sociology of Education 116-35.

Stepick, Alex (1989) "Miami's two informal sectors," in A. Portes et al., eds., T Informal Economy: Studies in Advanced and Less Developed Countries. Baltimore: Johns Hopkins Univ. Press.

Szacka, Alexandra (1984a) "Immigration et démographie," in P. Anctil \& G. Caldwell, eds., Juifs et réalités juives au quebec. Quebec: Institut Québécois de Recherche sur la Culture.

- (1984b) "Bases économiques et structure sociale 1931-1971," in P. Anctil \& G. Caldwell, eds., Juifs et réalités juives au quebec. Quebec: Institut Québécois de Recherche sur la Culture.

Torczyner, James L., \& Shari L. Brotman (1994) Diversity and Continuity: The Demographic Challenges Facing Montreal Jewry. Montreal: McGill Consortium for Ethnicity and Strategic Social Planning.

Van Hoy, Jerry L. (1993) "Prepackaged Law: The Political Economy and Organization of Routine Work at Multi-Branch Legal Services Firms," Ph.D. dissertation, Northwestern University

Wacquant, Loïc (1998) "Prologue: Social Structures and Mental Structures," in P. Bourdieu, The State Nobility: Elite Schools in the Field of Power. Stanford, CA: Stanford Univ. Press.

Waldinger, Roger D. (1996) Still the Promised City? African-Americans and New Immigrants in Post-Industrial New York. Cambridge, MA: Harvard Univ. Press. - (1997) "Social Capital or Social Closure? Immigrant Networks in the Labor Market," The Ralph and Goldy Lewis Center for Regional Policy Studies, UCLA, Working Paper Series No. 26.

Weinfeld, Morton (1980) "The Jews of Quebec: Perceived Antisemitism, Segregation, and Emigration," 22 Jewish J. of Sociology 5-20.

—_ (1993) "The Jews of Quebec," in R. J. Brym et al., eds., The Jews in Canada. Toronto: Oxford Univ. Press.

Weinfeld, Morton, \& William W. Eaton (1979) The Jewish Community of Montreal: Survey Report. Montreal: Jewish Community Research Institute of Montreal.

Westhead, Rick (1996) "Bailing Out of Quebec: Last Year's Referendum Has Left Many Quebec Lawyers Wondering: How Much Longer Can I Put Up with This?," 20 Canadian Lawyer 17-9.

Wilkins, David B. (1999) "Partners Without Power? A Preliminary Look at Black Partners in Corporate Law Firms," 2 J. for the Institute for the Study of Legal Ethics 15-48. 
(2004) "Doing Well by Doing Good? The Role of Public Service in the Careers of Black Corporate Lawyers," 41 Houston Law Rev. 1-91.

Wilton, Carol (1996) Inside the Law: Canadian Law Firms in Historical Perspective. Toronto: Published for the Osgoode Society for Canadian Legal History by Univ. of Toronto Press.

Woeste, Victoria Saker (2004) "Insecure Equality: Louis Marshall, Henry Ford, and the Problem of Defamatory Antisemitism, 1920-1929," 91 J. of American History 877905.

Wyatt, Nelson (1998) "PQ Wins Majority, but not Popular Vote," in Canadian Press News Wire, 1 December.

Yale Law Journal (1964) "The Jewish Law Student and New York Jobs-Discriminatory Effects in Law Firm Hiring Practice," 73 Yale Law J. 625-60.

Ronit Dinovitzer is a Social Sciences and Humanities Research Council of Canada postdoctoral fellow at Osgoode Hall Law School and Assistant Professor of Sociology at the University of Toronto. Her current research focuses on the social organization of the legal profession, and she is the coauthor of the recent report "After the JD: First Results of A National Study of Legal Careers" (NALP Foundation for Law Career Research and Education and the American Bar Foundation, 2004). Her other projects include a panel study of urban youth in Toronto and research on organizational culture in domestic violence courts. 
